2. To: (Receiving organization)

Distribution

5. Proj./Prog./Dept./Div.:

Flow Monitoring

8. Originator Remarks:

This EDT releases the System Design Description for the Double She 11 Tank Primary Exhaust Flow Monitoring System.

11. Receiver Remarks: 11A. Design Baseline Document? [] Yes [X] No
3. From: (originating Organization) Remote Sensing and Sampling Equipment Engineering

6. Design Authority/ Design Agent/Cog. Engr.:
4. Related EDT No.:

$\mathrm{N} / \mathrm{A}$

7. Purchase Order No.:

$N / A$

9. Equip./Component No.:

$N / A$

10. System/Btdg./Facility: 241-G

12. Major Assm. Dwg. No.:

H-14-100873

13. Permit/Permit Application No.: $\mathrm{N} / \mathrm{A}$

14. Required Response Date:

$N / A$

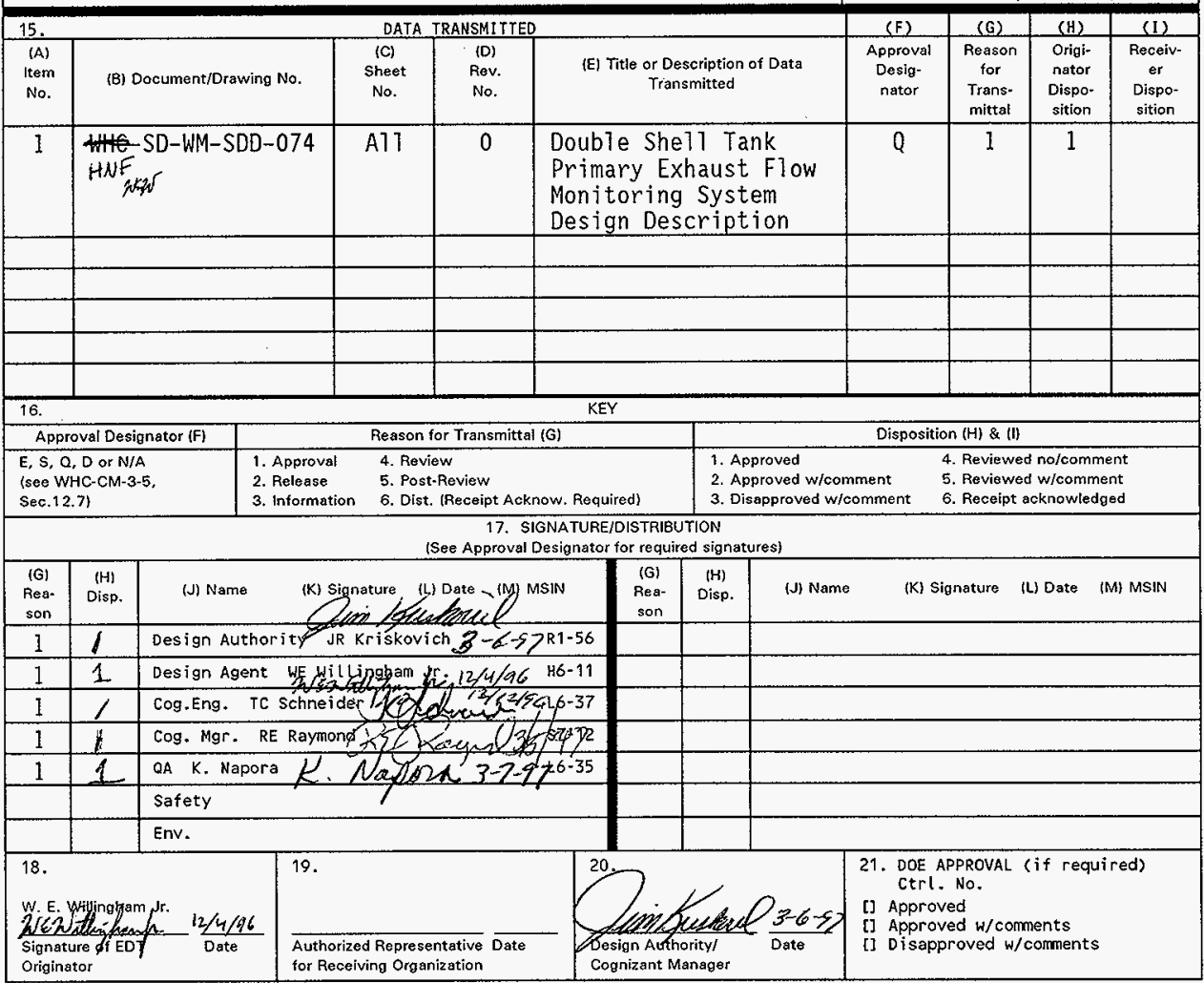




\title{
Double Shell Tank \\ Primary Ventilation Exhaust Flow Monitor System Design Description
}

\author{
W. E. Willingham Jr. \\ SGN Eurisys Services Corporation, Richland, WA 99352 \\ U.S. Department of Energy Contract DE-AC06-96RL13200 \\ EDT/ECN: 615721 \\ UC: 2070 \\ Org Code: $\$ 1200$ \\ Charge Code: N2051 \\ B\&R Code: EW3120072 \\ Total Pages: 15
}

Key Words: design description, flow monitoring, ventilation, double shell tanks, watch list, flammable gas

Abstract: This document describes the flow monitoring systems that wil? be installed on the ventilation exhaust ducts of the flammable gas watch 1ist double she 11 tanks (241-AN-103, 241-AN-104, 241-AN-105, 241-AN-107, 241-AW-101 and 241-SY-103), the saltwe 11 recejver tanks (241-AN-101 and 241-SY-102) and the cross-site receiver tank (241-AP-104).

TRADEMARK DISCLAIMER. Reference herein to any specific commercial product, process, or service by trade name, trademark, manufacturer, or otherwise, does not necessarily constitute or imply its endorsement, recommendation, or favoring by the United States Government or any agency thereof or its contractors or subcontractors.

Printed in the United States of America. To obtain copies of this document, contact: WHC/BCS Document Control Services, P.O. Box 1970, Mailstop H6-08, Richland WA 99352, Phone (509) 372-2420; Fax (509) 376-4989.
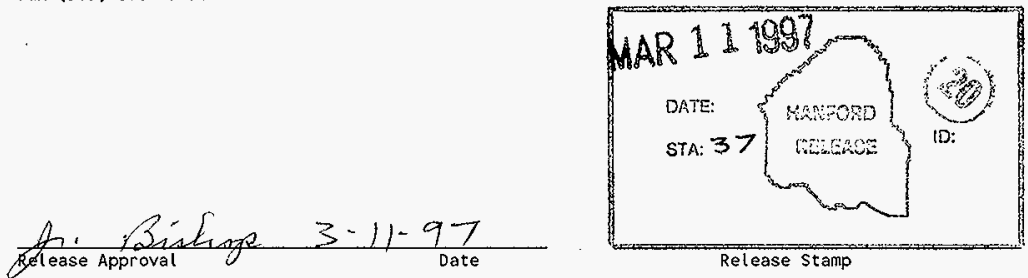

\section{Approved for Public Release}


Table of Contents

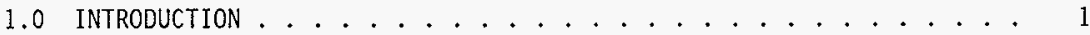

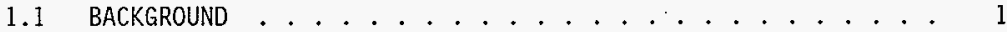

1.2 SCOPE. . . . . . . . . . . . . . 1

1.3 SYSTEM CLASSIFICATION .................. 1

2.0 FUNCTIONS AND DESIGN REQUIREMENTS ................ 2

2.1 INSTRUMENT ENCLOSURE REQUIREMENTS ............ 2

2.2 FLOW MONITORING SYSTEM REQUIREMENTS ........... 2

3.0 DESIGN DESCRIPTION . . . . . . . . . . . . . . . . . . . 3

3.1 DIFFERENTIAL PRESSURE SENSING SYSTEM . . . . . . . . . . . 3

3.2 TEMPERATURE SENSING SYSTEM ..................... 5

3.3 HVAC SYSTEM .......................... 6

3.4 POWER DISTRIBUTION $\ldots \ldots . \ldots 6$

4.0 SYSTTEM LIMITATIONS AND RESPONSE TO CASUALTY EVENTS . : . . . . . . 6

4.1 BREACH OF PRESSURE SENSING SYSTEM CONTAINMENT . . . . . . . 6

4.2 TOTAL LOSS OF ENCLOSURE POWER . . . . . . . . . . . . . 7

4.3 FLOW METER FAILURE ................... . . . . 7

4.4 LOSS OF ENCLOSURE HVAC . . . . . . . . . . . . . . 7

5.0 OPERATION . . . . . . . . . . . . . . . . . . . . . 7

5.1 SYSTEM STARTUP . . . . . . . . . . . . 7

5.2 PERFORM A FUNCTIONAL CALIBRATION ON EACH FLOW METER . . . 8

5.3 PERFORM A FUNCTIONAL CALIBRATION ON THE TEMPERATURE SENSING SYSTEM ...................... 8

6.0 Maintenance....................... 8

7.0 REFERENCES . . . . . . . . . . . . . . . . . . . . . 8

7.1 HANFORD COMPANY GENERATED ENGINEERING DOCUMENTS $\cdots \cdots$

7.2 GENERAL GOVERNMENT AND REGULATORY DOCUMENTS . . . . . . . 9

APPENDIX A - DRAWING LIST . . . . . . . . . . . 10

APPENDIX B - HVAC ANALYSIS .................... 10

APPENDIX C - MASS-tron II SET UP AND CALIBRATION PARAMETERS . . . . . . . 12 


\subsection{INTRODUCTION}

\section{$1.1 \quad$ BACKGROUND}

The air flow through the primary exhaust ventilation ducts of most Double Shell Tanks on the hydrogen watch 1 ist presently does not have the capability of bejng monitored continuously. A system has been designed to provide this capability and is planned to be installed on tanks 241-AW-101, 241-AN-101, 241-AN-103, 241-AN-104, 241-AN-105, 241-AN-107, 241-AP-104, 241-SY-102 and 241-SY-103. The system will have both a low range and a high range flow meter. The low range flow meter will monitor normal flow rates (from $0.25 \mathrm{~m} / \mathrm{s}(50 \mathrm{ft} / \mathrm{min})$ to $1.78 \mathrm{~m} / \mathrm{s}(350 \mathrm{ft} / \mathrm{min})$ ) while the high range flow meter will monitor flow during gas release events (up to $20 \mathrm{~m} / \mathrm{s}$ (3861 $\mathrm{ft} / \mathrm{min})$ ).

Flow monitoring, in conjunction with hydrogen monitoring equipment already installed, will allow for determination of the overall hydrogen generation and release rates. This information will assist in evaluating ventilation system effectiveness in resolving hydrogen safety issues.

\section{$1.2 \quad \underline{S C O P E}$}

This document describes the design of the Double Shell Tank Primary Ventilation Exhaust Flow Monitor system. Two flow meters and one temperature transmitter will be the analytical instruments employed to provide the exhaust flow data to be used in conjunction with the Standard Hydrogen Monitoring Systems (SHMS) data to determine the quantity of $\mathrm{flammable} \mathrm{gas} \mathrm{and} \mathrm{other} \mathrm{gas}$ species suspected to be generated in waste tanks, such as nitrous oxide $\left(\mathrm{N}_{2} \mathrm{O}\right)$, ammonia $\left(\mathrm{NH}_{3}\right)$, and methane $\left(\mathrm{CH}_{4}\right)$.

\subsection{SYSTEM CLASSIFICATION}

This flow monitoring system will be used to provide information only and will not be utilized for automatic control of the ventilation system. For this reason, this system is a General Service system as determined by the methodology of WHC-CM-4-46, Safety Analysis Manua7, section 9.0 (see Willingham Jr. 1997). However, the flame arresters provide defense-in-depth to existing Safety Class equipment and will be 1 isted as such on the Tank Farms Safety Equipment List. The function of the flame arresters is to quench any flame that may try to propagate down the tubing from the flow transmitters to the tank vapor spaces. 
HNF-SD-WM-SDD-074, REV. 0

Page 2 of 13

\subsection{FUNCTIONS AND DESIGN REQUIREMENTS}

The primary function of the Flow Monitor system is to provide exhaust duct flow rate data to be used in conjunction with gas concentration data to quantify the amount of flammable gasses being generated in Double Shell Hydrogen Watch List tanks. Current7y, of the 177 radioactive waste tanks on the Hanford Project site, twenty-five (six Double Shell Tanks and nineteen Single Sheil Tanks) were identified as having the potential for the buildup of gases to a flammable level.

The equipment has been selected based on testing in the $306 \mathrm{E}$ Laboratory to provide usable and traceable analytical data (Willingham Jr. 1996b).

The Flow Monitor system will transmit flow rate data to TMACS, with the option of transmitting process variables such as temperature and pressure.

The engineering tasks will comply with the requirements specified in WHC-SD-WM-ETP-156, Task Plan for Design and Instal7ation of Primary Exhaust Flow Monitoring in Double Shel7 Hydrogen Watch List Tanks (Groth 1995b).

\subsection{INSTRUMENT ENCLOSURE REQUIREMENTS}

It is necessary to provide an enclosure to house instruments for the analysis of exhaust duct air flow. The enclosure selected and support structure are identical to that being used for the Tank Monitor and Control System (TMACS) field instrumentation. The analysis for the enclosure installation, wind loading and seismic analysis for equipment anchorage are presented in WHC-SD-WM-DR-010, TMACS and Box Support Wind/Seismic Analysis. The enclosure requirements shall meet the following:

2.1 .1 The enclosures shall be installed in unprotected areas of the waste tank farms.

2.1.2 The enclosures shail be environmentally controlled in order to maintain the analytical equipment in an acceptable environment when the following external conditions exist:

- air temperature of -30 to $+50{ }^{\circ} \mathrm{C}\left(-20\right.$ to $\left.+120^{\circ} \mathrm{F}\right)$

- relative humidity of 10 to $80 \%$ condensing

- wind speeds up to $31.8 \mathrm{~m} / \mathrm{s}$ (70 miles/hour)

- rain, snow, sleet, lightning, hail, and blowing sand and dust

- radiation up to $30 \mathrm{mrem} / \mathrm{hour}$

\subsection{FLOW MONITORING SYSTEM REQUIREMENTS}

The flow monitoring system shall have the following requirements:

2.2.1 Measure the mass flow rate of air in a $30.48 \mathrm{~cm}$ (12 inch) diameter duct at an average flow velocity of 0.15 to $2.03 \mathrm{~m} / \mathrm{sec}$ $(30-400 \mathrm{ft} / \mathrm{min})$ with an accuracy of better than $\pm 0.08 \mathrm{~m} / \mathrm{sec}( \pm 15$ $\mathrm{ft} / \mathrm{min})$. 
2.2.2 Respond in less than ten seconds to a $50 \%$ step change in nominal flow rate.

2.2.3 Data shall be continuously logged to a data acquisition system, (a Standard Hydrogen Monitoring System (SHMS) or the Tank Monitor and Control System (TMACS)).

2.2.4 Transmit a 4-20 mA signal proportional to mass flow rate.

2.2.5 Have a design life of five years for replaceable components and twenty years for non-replaceable components.

2.2.6 Utilize electrical power from the associated SHMS cabinet.

2.2.7 Be readily maintainable in the field.

\subsection{DESIGN DESCRIPTION}

The flow monitoring system design includes several major subsystems which make up the Primary Ventilation Exhaust Flow Monitor system (see Figure 1).

- The differential pressure sensing system is composed of tubing, valves and an airflow traverse probe that delivers the pressure sample to the flow meters.

- The temperature sensing system includes the temperature sensor and temperature transmitter, and is used to provide a temperature compensation signal to the flow meters.

- The enclosure HVAC system maintains the enclosure ambient temperature within the instruments' specified operating range, minimizing the data errors due to temperature change.

- The power distribution system is composed of unconditioned $A C$ power for instruments and HVAC.

\subsection{DIFFERENTIAL PRESSURE SENSING SYSTEM}

The differential pressure sensing system includes all the components that sense the total and static pressures in the exhaust duct and conduct those pressures to the flow transmitters.

\subsubsection{Airflow Traverse Probes}

The airflow traverse probes are used to sense total pressure and static pressure in the exhaust ducts. The probes utilize separate total and static pressure averaging manifolds. They are constructed of type 316 stainless steel. 
HNF-SD-WM-SDD-074, REV. 0

Page 4 of 13

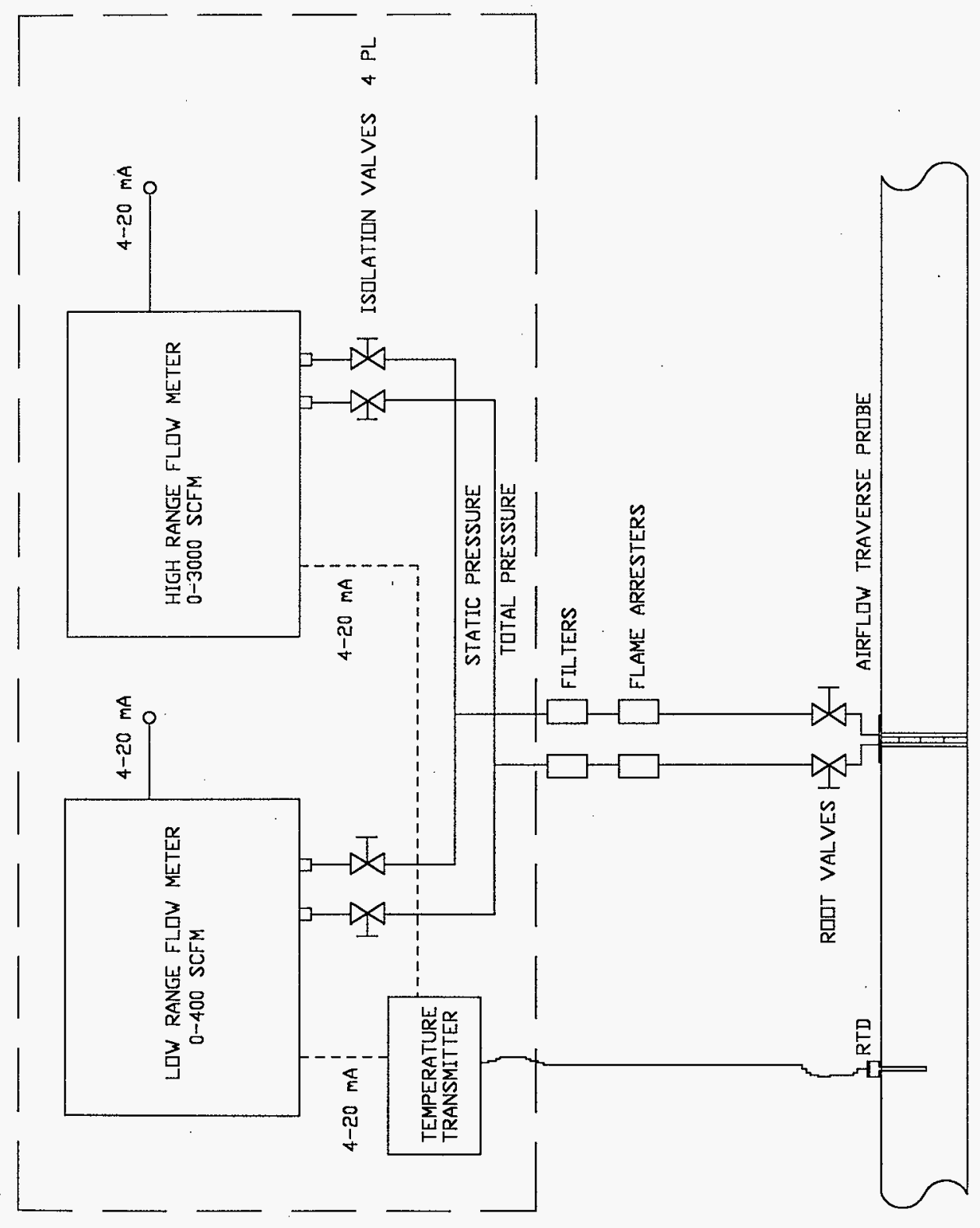

FIGURE 1 


\subsubsection{System Tubing and Fittings}

The system tubing and fittings are 300 series stainless steel in order to withstand the potentially corrosive gases being sampled. The two sensing 1 ines between the air traverse probes and the and the flow meter enclosures are $0.635 \mathrm{~cm}$ (1/4 inch) diameter for resistance to any physical damage that may occur. The sensing lines inside the enclosure are $0.3175 \mathrm{~cm}(1 / 8$ inch) diameter for ease of construction and space saving. The tubing provides a pressure conduction media, but there is no gas flow through the tubing.

\subsubsection{System Root Valves and Isolation Valves}

The system root valves and isolation valves are constructed of 300 series stainless steel. Ball valves are selected to provide positive indication of valve position during system operation. Instrumentation isolation valves are provided to allow removal of the flow meters for calibration. The root valves serve as system isolation valves.

\subsubsection{Flame Arresters}

The $f 7$ ame arresters are constructed with a 316 stainless steel housing and a 304 stainless steel flame barrier and provide protection against flame propagation to the tank vapor space in the event of system failure on the other side of the barrier. The flame arresters are approved per NFPA for use with Group B gases (hydrogen).

\section{$3.1 .4 \quad$ Filters}

The filters are constructed of 316 stainless steel and have a claimed filtration efficiency rating of $100 \%$ for 0.2 micron level. They use a fiberglass. filter media to entrap or adsorb particles. The filters are intended to keep the interior of the tubing and flow transmitters free of contamination.

\subsubsection{Mass Flow Transmitters}

The flow meters used are Air Monitor Corporation MASS-tron II ultra-low differential pressure transmitters. They feature a periodic automatic zeroing circuit to eliminate zero drift due to thermal, electronic or mechanical effects. The input pressure bulkhead connectors are constructed of brass. The tubing between the input connectors and the automatic zeroing valve and pressure sensor are $0.3175 \mathrm{~cm}\left(1 / 8^{\prime \prime}\right)$ plastic tubing.

\subsection{TEMPERATURE SENSING SYSTEM}

The temperature sensing system includes the temperature sensor and the temperature transmitter. The temperature data is used by the flow meters to convert the flow rate data to standard conditions. 


\subsubsection{Temperature Sensor}

The temperature sensor used is a three-wire 100 ohm platinum RTD. The insertion-type probe is constructed of type 316 stainless. steel and has an explosion proof head. The RTD elements conform to DIN specification 43760 and have a temperature coefficient of $0.00385 \mathrm{ohms} / \mathrm{ohm} /{ }^{\circ} \mathrm{C}$.

\subsubsection{Temperature Transmitter}

The temperature transmitter provides a constant current excitation to the RTD. It also measures the voltage drop across the RTD and transmits a 4-20 mA output signal proportional to the measured temperature.

\subsection{HVAC SYSTEM}

The flow monitoring system must operate during all seasons on the selected tank farms without additional environmental protection. Since the instruments must be able to perform during wide outside ambient temperature conditions, an insulated enclosure with an HVAC system has been used. The HVAC unit uses thermoelectric cooling and resistive heating. Thermoelectric cooling is a solid-state method of heat transfer generated through the use of dissimilar semiconductor materials. There are no refrigerants or moving parts used in this refrigeration method other than a fan used for air circulation. The unit used can supply about 146 watts $(500 \mathrm{BTU} / \mathrm{hr})$ of cooling and 175 watts (600 BTU/hr) of heating.

\subsection{POWER DISTRIBUTION}

The AC power is supplied from sources convenient to the installation. Possible sources are Standard Hydrogen Monitoring System (SHMS) enclosures, panelboards in the field or panelboards in the instrument buildings. Each flow monitoring enclosures uses about 5 amperes maximum at 120 VAC.

\subsection{SYSTEM LIMITATIONS AND RESPONSE TO CASUALTY EVENTS}

The flow monitoring system contains the pressure samples in stainless steel for the duration of its path outside the tank vapor space. The entire system is under negative pressure as provided by the tank ventilation system. These two barriers, the stainless steel and negative pressure, provide the containment for the pressure samples. The following paragraphs identify postulated system limitations and casualty events and potential responses.

\subsection{BREACH OF PRESSURE SENSING SYSTEM CONTAINMENT}

The failure of the pressure sensing containment components would provide a path to atmosphere. Since the system will be initially leak checked with pressure, and routinely checked during its operational life, the only credible path to atmosphere would be from an accident. 
The result of a system breech would be to allow inflow of atmosphere, raising the sensed pressure, thus providing erroneous signals to the analytical instruments. This will be managed administratively by Operations.

\subsection{TOTAL LOSS OF ENCLOSURE POWER}

Total loss of enclosure power will terminate the flow monitoring system operation. Flow monitoring will.be suspended until power is restored. Upon restoration of power the system should resume normat operation without human intervention.

\subsection{FLOW METER FAILURE}

Failure of a single flow meter will not totally terminate the flow monitoring capability. The high range flow meter span overlaps the low range flow meter span. Normal ventilation flow will be within the low range.span and gas release event ventilation flow will be within the low range span.

\subsection{LOSS OF ENCLOSURE HVAC}

Loss of enclosure HVAC will affect the quality of the flow monitoring data. A prolonged outage may require the system equipment power to be removed. The operation of the flow monitoring system will be administratively controlled during loss of enclosure HVAC.

\subsection{OPERATION}

The operation of the flow monitoring system will permit the continual sensing and monitoring of the exhaust duct flow rate. Accurate flow measurement, in conjunction with gas concentration measurements, will allow quantitization of baseline gas generation as well as larger gas release events.

\subsection{SYSTEM STARTUP}

The system startup is a minor evolution in the system operation. The following provides a proposed sequence of events for startup. (It should be noted that a functional leak check should be performed before system energization.)

5.1.1 Verify that the enclosure power is available.

5.1.2 Energize the HVAC system and establish the enclosure environmenta 7 control between 10 and $35{ }^{\circ} \mathrm{C}\left(50\right.$ and $\left.95{ }^{\circ} \mathrm{F}\right)$.

5.1.3 Verify the position of all the manual valves.

5.1.4 Energize each of the powered instruments and verify nominat indications. 
5.1.5 Verify the following parameters are acceptable:

- each flow meter is displaying the same differential pressure.

- each flow meter is displaying the same temperature.

- each flow meter is displaying the same static pressure.

(These will be slightly different due to system tolerances and range differences.)

5.1.6 Verify that the instrumentation signals are being transmitted and received by TMACS.

\subsection{PERFORM A FUNCTIONAL CALIBRATION ON EACH FLOW METER}

The two flow meters will require a functional calibration on a routine basis. The procedure may require Maintenance, Operations and Taboratory support personnel.

\subsection{PERFORM A FUNCTIONAL CALIBRATION ON THE TEMPERATURE SENSING SYSTEM}

The temperature transmitter will require a functional calibration on a routine basis. The procedure may require Maintenance, Operations and laboratory support personne].

\subsection{MAINTENANCE}

The flow monitoring system will require routine maintenance to support continual operation. Detailed maintenance procedures will cover the general maintenance activities. Some of the maintenance activities, such as calibration of the flow transmitters, will be performed by laboratory support personnel. The following is a general listing of maintenance operations.

6.1 Calibration of each flow meter.

6.2 Calibration of the temperature transmitter.

6.3 Cleaning of heat sink fins on exterior portion of HVAC unit.

\subsection{REFERENCES}

\subsection{HANFORD COMPANY GENERATED ENGINEERING DOCUMENTS}

Groth, B.D.; 1995a, Design Requirements Document - Primary Ventilation Flow Monitoring for DSTs on the Hydrogen Watch List, WHC-SD-WM-DRD-003, Rev. 0 , Westinghouse Hanford Company, Richland, Washington. 
Groth, B.D., 1995b, Task Plan for Design and Installation of Primary Exhaust Ventilation Flow Monitoring in Double She7l Hydrogen Watch List Tanks, WHC-SD-WM-ETP-156, Rev. 0, Westinghouse Hanford Company, Richland, Washington.

Hertelendy, N.A., 1995a, Engineering Study and Conceptual Design Report for Primary Ventilation Duct Flow Monitoring, WHC-SD-WM-CDR-026, Rev. 0, Westinghouse Hanford Company, Richland, Washington.

Hertelendy, N.A., 1995b, Task Plan for the Selection and Evaluation of Flow Monitoring Instrumentation to be Used on the Primary Exhaust Ventilation in Double Shell Hydrogen Watch List Tanks, WHC-SD-WM-ETP-178, Rev. 0, Westinghouse Hanford Company, Richland, Washington.

Peterson, W.S., 1993, TMACS and Box Support Wind/Seismic Analysis, WHC-SD-WM-DR-010, Rev. 0, Westinghouse Hanford Company, Richland, Washington.

Willingham Jr., W.E., 1996a, Test Plan for Evaluation of Primary Exhaust Ventilation Flow Meters for Double Shell Hydrogen Watch List Tanks, WHC-SD-WM-TP-441, Rev. O, ICF Kaiser Hanford Company, Richland, Washington.

Willingham Jr., W.E., 1996b, Test Report of Evaluation of Primary Exhaust Ventilation Flow Meters for Double She 77 Hydrogen Watch List Tanks, WHC-SD-WM-TRP-254, Rev. 0, ICF Kaiser Hanford Company, Richland, Washington.

Willingham Jr., W.E., 1997, Technical Basis for Installation of the Double She77 Tank Exhaust Flow Monitoring Systems, HNF-SD-WM-ER-629, Rev. 0, SGN Eurisys Services Corporation, Richland, Washington.

\subsection{GENERAL GOVERNMENT AND REGULATORY DOCUMENTS}

DOE, 1989, General Design Criteria, D0E order 6430.1A, U.S. Department of Energy, Washington, D.C.

NFPA, 1996, National Electrical Code, NFPA 70, National Fire Protection Association, Quincy, Massachusetts. 


\section{APPENDIX A - DRAWING LIST}

DRAWING NO.

H-14-100873

\section{TITLE}

DOUBLE SHELL TANK PRIMARY VENTILATION EXHAUST FLOW MONITORING SYSTEM

\section{APPENDIX B - HVAC ANALYSIS}

This appendix addresses the design analysis of the HVAC system for flow monitoring system.

Flow Monitoring System - HVAC Electrical Heat Loads

GENERAL DESIGN DATA

* Design Conditions: Summer: $\quad 49^{\circ} \mathrm{C}\left(120^{\circ} \mathrm{F}\right)$

Winter: $\quad-18{ }^{\circ} \mathrm{C}\left(0^{\circ} \mathrm{F}\right)$

Wind: $\quad 112 \mathrm{~km} / \mathrm{hr}$ (70 $\mathrm{mph}$ )

* Interior Design Temperature: $\quad 21 \pm 8{ }^{\circ} \mathrm{C}\left(70 \pm 15^{\circ} \mathrm{F}\right)$

ASSUMPTIONS

* No air infiltration or exfiltration

* Equipment runs continuously and is in operation simultaneously

Flow Monitoring Enclosure Internal Heat Sources

$\begin{array}{rlrrr}\underline{0 T Y} & \text { Description } & \underline{\mathrm{V} / \mathrm{Hz} / \mathrm{Ph}} & \underline{\text { A } / \text { ea }} & \text { VA } \\ 2 & \text { Mass Flow Transmitter } & 120 / 60 / 1 & 0.156 & 18.7 \\ 1 & \text { Temperature Transmitter } & 120 / 60 / 1 & 0.042 & 5\end{array}$

TOTAL INTERNAL HEAT GAIN $\left(Q_{e}\right)=42.4$ VA (watts)

$(42.4$ Watts $) *(3.414 \mathrm{BTU} / \mathrm{Hr} / \mathrm{Watt})=145 \mathrm{BTU} / \mathrm{Hr}$ 
Ambient Thermal Load

Exposed surface area of enclosure $\left(S_{a}\right)=14.68 \mathrm{sq} . \mathrm{ft}$.

Maximum ambient air temperature $\left(\mathrm{T}_{\mathrm{a}}\right)^{\mathrm{a}}=120^{\circ} \mathrm{F}$

Maximum allowable enclosure air temperature $\left(T_{e}\right)=100^{\circ} \mathrm{F}$

Insulation thickness $=1 "$ urethane

From TECA catalog: $x=0.073, y=1.119$

$Q_{a}=x S_{a}\left(T_{a}-T_{e}\right)^{y}=30.6 \mathrm{BTU} / \mathrm{Hr}$

Total Thermal Load

Total thermal load equals internal enclosure load plus ambient thermal load plus radiated or solar loads. The support stands have sunshields on them and are to be installed such that the sunshield is on the south facing side, minimizing the solar load.

Total thermal load $=145+30.6=176 \mathrm{BTU} / \mathrm{Hr}$.

The air rating of the solid state air conditioner is 425-485 BTU/Hr, leaving a reserve of about $280 \mathrm{BTU} / \mathrm{Hr}$ for any solar loads encountered. 
HNF-SD-WM-SDD-074, REV. 0

Page 12 of 13

\section{APPENDIX C - MASS-tron II SET UP AND CALIBRATION PARAMETERS}

\begin{tabular}{|c|c|c|}
\hline & High Range & Low Range \\
\hline AUTO-ZERO & ON & ON \\
\hline 4 LINE DISPLAY & ON & ON \\
\hline AUTO-PURGE & OFF & OFF \\
\hline AP ACTIVATION & INTRNL \& EXTRNL & INTRNL \& EXTRNL \\
\hline ALARM SELECTION & OFF & OFF \\
\hline TRANSDUCER TYPE & UNIPOLAR & UNIPOLAR \\
\hline K-FACTOR & OFF & OFF \\
\hline FLOW TYPE & MASS & MASS \\
\hline $\begin{array}{l}\text { TEMPERATURE/PRESSURE } \\
\text { SELECT }\end{array}$ & TEMP and PRESS & TEMP and PRESS \\
\hline TEMPERATURE UNITS & ${ }^{\circ} \mathrm{F}$ & ${ }^{\circ} \mathrm{F}$ \\
\hline TEMPERATURE LINEARIZATION & NOT REQUIRED & NOT REQUIRED \\
\hline AZ INTERVAL & $1 \mathrm{HR}$ & $1 \mathrm{HR}$ \\
\hline SQ ROOT LOCKDOWN & $10 \%$ & $7 \%$ \\
\hline MIN TEMPERATURE & $0^{\circ} \mathrm{F}$ & $0^{\circ} \mathrm{F}$ \\
\hline MAX TEMPERATURE & $200^{\circ} \mathrm{F}$ & $200^{\circ} \mathrm{F}$ \\
\hline MIN PRESSURE & $24.00^{\prime \prime ~ H g}$ & $24.00^{11} \mathrm{Hg}$ \\
\hline MAX PRESSURE & $32.00 \mathrm{l} \mathrm{Hg}$ & $32.00^{\prime \prime} \mathrm{Hg}$ \\
\hline Function select & NONE & NONE \\
\hline Int. MULTIPLIER & 1.000 & 1.000. \\
\hline Ext. MULTIPLIER & 1.000 & 1.000 \\
\hline OUTPUT 2 SELECT & TEMPERATURE & TEMPERATURE \\
\hline OUTPUT 3 SELECT & ABS. PRESSURE & ABS. PRESSURE \\
\hline OUTPUT 4 SELECT & NO OUTPUT & NO OUTPUT \\
\hline LINE 1 PARAMETER & TRANSMITTER FLOW & TRANSMITTER FLOW \\
\hline LINE 1 UNITS & FLOW SCFM & FLOW SCFM \\
\hline LINE 1 FORMAT & FLOW $X X, X X X \quad$ SCFM & FLOW $X X, X X X \quad$ SCFM \\
\hline LINE I ZERO & FLOW 0 SCFM & FLOW 0 SCFM \\
\hline LINE 1 SPAN & FLOW 3000 SCFM & FLOW 400 SCFM \\
\hline LINE I FILTER & Xmit Filter $\div 2$ & Xmit Filter $\div 2$ \\
\hline
\end{tabular}




\begin{tabular}{|c|c|c|}
\hline & High Range & Low Range \\
\hline LINE 2 PARAMETER & TEMPERATURE & TEMPERATURE \\
\hline LINE 3 PARAMETER & ABSOLUTE PRESSURE & ABSOLUTE PRESSURE \\
\hline LINE 4 PARAMETER & NONE & NONE \\
\hline LOW PASS FILYER & Freq: $0.500 \mathrm{~Hz}$ & Freq: $0.500 \mathrm{~Hz}$ \\
\hline \multicolumn{3}{|l|}{ SWITCH POSITIONS } \\
\hline S2 & POS 0 & POS 0 \\
\hline S3 (AZ VALVE) & DOWN & DOWN \\
\hline$\$ 4$ & POS 4 & POS 4 \\
\hline S5 (AS VALVE) & DOWN & DOWN \\
\hline$S 6$ (CALIB) & DOWN & DOWN \\
\hline S10 (DISPLAY) & DOWN & DOWN \\
\hline S11 (CNTRLR) & DOWN & DOWN \\
\hline \multicolumn{3}{|l|}{ JUMPER POSITIONS (JI) } \\
\hline & $3-5$ & $3-5$ \\
\hline & $4-6$ & $4-6$ \\
\hline & $19-21$ & $19-21$ \\
\hline & $20-22$ & $20-22$ \\
\hline . & $23-25$ & $23-25$ \\
\hline & $39-41$ & $39-41$ \\
\hline & $43-45$ & $43-45$ \\
\hline . & $49-51$ & $49-51$ \\
\hline
\end{tabular}




\section{DISTRIBUTION SHEET}

\begin{tabular}{|c|c|c|c|c|c|}
\hline \multirow{2}{*}{$\begin{array}{l}\text { To } \\
\text { Distribution }\end{array}$} & \multirow{2}{*}{\multicolumn{3}{|c|}{$\begin{array}{l}\text { From } \\
\text { W. E. Willingham Jr. }\end{array}$}} & \multicolumn{2}{|c|}{ Page 1 of 1} \\
\hline & & & & \multicolumn{2}{|c|}{ Date $3 / 7 / 97$} \\
\hline \multirow{2}{*}{\multicolumn{4}{|c|}{$\begin{array}{l}\text { Project Title/Work Order } \\
\text { Characterization }\end{array}$}} & \multicolumn{2}{|c|}{ EDT No. 615721} \\
\hline & & & & \multicolumn{2}{|c|}{ ECN No. } \\
\hline Name & MSIN & $\begin{array}{c}\text { Text } \\
\text { With All } \\
\text { Attach. }\end{array}$ & Text Only & $\begin{array}{l}\text { Attach./ } \\
\text { Appendix } \\
\text { Only }\end{array}$ & $\begin{array}{l}\text { EDT/ECN } \\
\text { Only }\end{array}$ \\
\hline $\begin{array}{l}\text { W. E. Willingham Jr. } \\
\text { C. E. Hanson } \\
\text { T. C. Schneider } \\
\text { D. D. Tate } \\
\text { D. W. Crass } \\
\text { K. Napora } \\
\text { C. C. Scaief III } \\
\text { J. R. Kriskovich } \\
\text { R. E. Raymond } \\
\text { J. Lohrasbi } \\
\text { T. D. Kaiser } \\
\text { R. S. Nicholson } \\
\text { K. A. White } \\
\text { M. J. Sutey } \\
\text { Central Files }\end{array}$ & $\begin{array}{l}H 6-11 \\
S 7-12 \\
\text { L6-37 } \\
\text { L6-37 } \\
\text { H5-68 } \\
\text { L6-35 } \\
\text { R1-56 } \\
\text { R1-56 } \\
\text { S7-12 } \\
\text { S5-05 } \\
\text { T4-07 } \\
\text { S5-05 } \\
\text { S5-09 } \\
\text { T4-08 } \\
\text { A3 } 3-88\end{array}$ & $\begin{array}{l}X \\
X \\
X \\
X \\
X \\
X \\
X \\
X \\
X \\
X \\
X \\
X \\
X \\
X \\
X\end{array}$ & & & \\
\hline
\end{tabular}

